DOI: 10.17951/lrp.2019.38.3.13-31

\author{
JAROSŁAW JAGIEŁA \\ Uniwersytet Humanistyczno-Przyrodniczy im. J. Długosza w Częstochowie \\ Wydział Nauk Społecznych \\ ORCID - 0000-0001-5025-076X
}

\title{
„BO WE MNIE ZDROWIE I SIŁA JEST...” \\ EDUKACYJNA ANALIZA TRANSAKCYJNA Z PERSPEKTYWY POZYTYWNEJ PSYCHOPEDAGOGIKI
}

\begin{abstract}
Streszczenie: Analiza transakcyjna (AT) jako jeden z kierunków psychoterapii od początku swojego istnienia kierowała się założeniami bliskimi psychologii pozytywnej. Na ten fakt zwraca uwagę wielu autorów publikujących w „Transactional Analysis Journal”. Implementacje analizy transakcyjnej do edukacji i pojawiające się tutaj problemy, modele i rozwiązanie dodatkowo zwiększają zaangażowanie tej koncepcji w kierunku współcześnie rozumianej psychologii pozytywnej.
\end{abstract}

Słowa kluczowe: psychologia pozytywna, analiza transakcyjna, edukacyjna analiza transakcyjna

Celem niniejszego artykułu jest wykazanie, że inkluzja edukacji w obszar tradycyjnie zorientowanej psychoterapeutycznie analizy transakcyjnej przyczyniła się do pozytywnej orientacji tego kierunku. Mimo że elementy afirmatywnej psychologii były obecne w analizie transakcyjnej (AT) od początku jej istnienia, na co wskazuje wielu autorów, to jednak problematyka nauczania i wychowania dodatkowo umocniła ten kierunek przemian. Przesunęła akcenty zainteresowań z patologii, zaburzeń psychicznych i braku normatywności oraz dróg im przeciwdziałania $w$ postaci terapii na pozytywne aspekty funkcjonowania i rozwoju człowieka. Tytuł artykułu nawiązuje do przesłania, jaki wiąże się z jedną z ważnych, dostępnych polskiemu czytelnikowi książek, poświęconych psychologii pozytywnej (Carr 2009). 


\section{W KIERUNKU PSYCHOLOGII POZYTYWNEJ}

$\mathrm{W}$ jednym $\mathrm{z}$ najlepszych słowników psychologicznych pojęcie psychologii pozytywnej (PP - positive psychology) określana jest jako: „psychologia cenionych zjawisk psychicznych, takich jak zadowolenie i satysfakcja (dotyczące przeszłości), nadzieja i optymizm (na przyszłość) oraz szczęście i dobrostan (w teraźniejszości). Koncentruje się na subiektywnie pozytywnych doświadczeniach, takich jak miłość i podobanie się; pozytywnych cechach jednostki, takich jak odwaga, umiejętności interpersonalne, wytrwałość, oryginalność i mądrość, pozytywnych zjawiskach społecznych, takich jak kooperacja, altruizm i tolerancja” (Colman 2009, s. 609). Nie bez znaczenia jest także pojęcie zdrowia fizycznego i psychicznego. Dalej przytaczany jest Martin E.P. Seligman jako twórca tego pojęcia, ale też pozostałe osoby oraz czasopisma, które przyczyniły się do jego upowszechnienia. I choć pojęcie psychologii pozytywnej nie jest nowe, a jego znaczenia można doszukiwać się przynajmniej pół wieku przed tym autorem, to jednak zasług Seligmanna $\mathrm{w}$ propagowaniu i upowszechnianiu wspomnianego nurtu współczesnej psychologii nie można zakwestionować.

Przedstawiciele psychologii pozytywnej dość zgodnie twierdzą, że nauka ta była dotąd nadmiernie skoncentrowana - podobnie zresztą, jak i inne dyscypliny społeczne - na problematyce negatywnej strony życia ludzkiego, gdzie patologia, zaburzenia i wszelkiego rodzaju urazy psychiczne, choroby oraz deficyty zajmowały poczesne miejsce. Kierują zatem naszą uwagę ku pozytywnym aspektom pełni egzystencji, szczęściu i rozwojowi. Trzeba jednak podkreślić, że jednocześnie nie negują dotychczasowego sposobu uprawiania psychologii, nie pragną tworzyć konkurencji, ale stwarzają ramy dla jej uzupełnienia oraz zbalansowania dotychczasowego stanu rzeczy w celu osiągnięcia pełni życia (Seligman, Parks, Steen 2004, s. 1379-1381)

W rozważaniach nad istotą przedmiotową oraz zakresem pojęciowym psychologii pozytywnej nie sposób nie sięgnąć do obszernego wieloautorskiego dzieła Handbook of Positive Psychology pod redakcją Charlesa R. Snydera i Shane J. Lopeza. Psychologia pozytywna - jak twierdzą autorzy tego dzieła - ma na celu głębsze zrozumienie pozytywnych emocji, cech pozytywnych i pozytywnych instytucji. W ubiegłych latach psychologia koncentrowała się głównie na analizie zaburzeń psychicznych i ludzkiego cierpienia. Szczęście było postrzegane po prostu jako brak ludzkiej udręki, jednak nigdy nie było tak naprawdę dogłębnie studiowane. Celem Seligmana, którego studium otwiera ten tom, nie było zastąpienie tradycyjnej psychologii nową dziedziną, ale zbudowanie pełniejszego obrazu ludzkiego doświadczenia. Bez wątpienia inspiracją była tu psychologia humanistyczna. To spowodowało przesunięcie uwagi z głównego przedmiotu psychologii, jakim jest 
analiza poszczególnych zagadnień psychologicznych, w kierunku analizy zdrowia psychicznego i odczuwania szczęścia. Od początku psychologia pozytywna koncentrowała się na takich zagadnieniach, jak: życiowy optymizm, samoocena jednostki, jej dobrostan oraz motywacja do działania, a także mocne strony i cnoty, nadzieja czy pozytywne myślenie. Skupiano się na trzech obszarach pozytywnych doświadczeń: przeszłości (dobre samopoczucie i zdrowie oraz zadowolenie z upływającego życia), teraźniejszości (odczuwanie szczęścia) oraz przyszłości (z perspektywą nadziei i optymizmu). Te trzy dziedziny badań wyznaczały i nadal wyznaczają kierunek pozytywnych interwencji służących zwiększeniu ludzkiego szczęścia i ogólnego dobrego nastroju. Interwencje tego rodzaju są nakierowane na różne środowiska i obszary ludzkiej aktywności, takie jak edukacja, zasoby ludzkie, funkcjonowanie struktur organizacyjnych, doradztwo zawodowe, terapia i zdrowie.

Wspomniany Martin E.P. Seligman, niekwestionowany prekursor tego kierunku, definiuje psychologię pozytywną następująco: „Psychologia nie jest już więc nauką dotyczącą choroby, defektu czy słabości człowieka, ale również badaniem jego siły, zalet, mocnych stron i skuteczności. Podejście to nie koncentruje się na tym co jest nie takie jak być powinno, ale buduje to co dobre i odpowiednie dla człowieka. Nie jest to nauka tylko o chorobach czy zdrowiu, ale obejmuje sfere pracy, edukacji, intuicji, miłości czy rozwoju i zabawy" (Seligman 2005, s. 4). Dalej autor opisuje pięć czynników dobrego samopoczucia: pozytywne emocje, zaangażowanie, relacje $z$ innymi, poczucie znaczenia oraz cel i pragnienie jego osiągnięcia. Ujmuje to w akronim: PERMA.

W omawianym tu obszernym tomie, bo liczącym ponad osiemset stron, odejmujemy też wielu innych znanych autorów i zagadnienia, jakim poświęcają swoje studia, bazując na podejściu poznawczym, emocjonalnym, interpersonalnym czy biologicznym. Pojawiają się tu zatem takie pojęcia, jak: dobrostan (well-being), autentyczność, optymizm, nadzieja, współczucie, pokora, empatia, miłość i duchowość. Wybrani autorzy przedstawiają też koncepcję psychologii pozytywnej dziecka i rozwoju człowieka, kontekstu multikulturowego oraz deklaracje i zakładane perspektywy dotyczące dalszego rozwoju koncepcji czy przyszłych obszarów możliwych zastosowań tej dziedziny. Dziedziny, która została zapoczątkowana w 1998 roku przez Seligmana, mimo że jej korzenie sięgają starożytności oraz Arystotelesa i jego pojęcia eudajmonicznego (od daimon) dobrostanu, co oznaczało prawdziwą naturę człowieka. Arystoteles nie uważał jednak, że każde dążenie do szczęścia zasługuje na akceptację i prowadzi do dobrego samopoczucia, ale tylko to, które pochodzi od prawdziwie cnotliwego życia.

Równie szeroki zakres pojęć mieszczących się w pozytywnej psychologii zawiera obszerna monografia Alana Carra (2009). Autor jest profesorem i dyrektorem studium doktoranckiego w zakresie psychologii klinicznej na University College 
w Dublinie oraz konsultantem i terapeutą rodzin i małżeństw w Clanwilliam Institute for Martial and Family Therapy w tym samym mieście. Odnajdujemy tu zarówno refleksję nad ludzkim szczęściem, posiadaniem optymalnego doświadczenia życiowego, rozwoju inteligencji emocjonalnej, związków nadziei i optymizmu ze zdrowiem, motywacji, kreatywności i mądrości, gotowości, jak i kwestią relacji międzyludzkich oraz zagadnień budowania pozytywnego Ja.

Czynniki sprzyjające ludzkiemu spełnieniu odnajdujemy w książce Jonathana Haidta, która zyskała miano światowego bestsellera, a która ukazała się pod znamiennym tytułem Szczęście (Haidt 2007). Pojawia się tu odpowiedź na źródła psychologii pozytywnej tkwiące w starożytnych mądrościach i ich obecności w dobie współczesnej. Autor w jednym z rozdziałów stawia tezę, że szczęście polega na wychodzeniu poza siebie i budowaniu zaangażowanych więzi z innymi. Podkreśla: „Szczęście pochodzi z spomiędzy” (Haidt s. 384). Ludzie są tu ujmowani wielopoziomowo jako istoty fizyczne, umysłowe oraz społeczne i kulturowe, a człowiek nabywa poczucia, że jego życie nabiera sensu, gdy osiąga spójność między trzema wspomnianymi poziomami egzystencji.

Szeroki zakres tematyki psychologii pozytywnej zawiera polska monografia obejmująca prace znanych autorów zagranicznych m.in. Martina E.P. Seligmana, Paula B. Baltensa, Martina Argyle czy Davida G. Mayersa (Czapiński 2004). Ostatni z autorów stara się wykazać korelacje między bliskimi związkami międzyludzkimi a jakością życia. Wskazuje na znaczenie i wzrastającą popularność ruchu społecznego, który określany jest jako komunitarianizm działający na rzecz takich zasad postępowania, które starają się utrzymać równowagę między indywidualizmem a wspólnotowością i prawami osobistymi a społeczną odpowiedzialnością. Jest to swoista homeostaza między skrajnym kolektywizmem a radykalnym indywidualizmem, mogąca zapewnić optymalne relacje międzyludzkie.

Wśród innych polskich publikacji na uwagę zasługuje refleksja upatrująca w ponoszonych przez ludzi porażkach również aspektów pozytywnych. Paweł Fortuna pisze: „Chciałbym przyjrzeć się porażce jako ważnemu czynnikowi prorozwojowemu, potencjalnie kierującemu nas ku lepszemu życiu. Myślę, że takie spojrzenie jest możliwe właśnie dzięki psychologii pozytywnej. Integrując wielowiekową refleksję nad źródłami dobrego życia, dziedzina ta dostarcza wskazówek ułatwiających studiowanie sytuacji trudnych pod kątem ich siły sprawczej, zbliżającej człowieka do osiągnięcia szczęścia. Siły charakteru nie tylko pokonywanie życiowych zakrętów, ale także same uzyskują w tych sytuacjach szlif. Mamy więc do czynienia $\mathrm{z}$ ważnym zasobem, który - odpowiednio spożytkowany - może sprzyjać wzrostowi osobistemu" (Fortuna 2012, s. 11-12).

Interesującym przedmiotem dyskursu byłaby refleksja na temat obecności tego rodzaju pozytywnej orientacji w poszczególnych nurtach teoretycznych psychologii. 
Występowanie, w mniejszym lub większym stopniu, założeń i wątków pozytywnej psychologii, można dostrzec niemal we wszystkich kierunkach refleksji nad życiem psychicznym człowieka, zaczynając od najstarszych nurtów i prądów intelektualnych. Jednym z takich wyodrębnionych kierunków jest analiza transakcyjna.

\section{ANALIZA TRANSAKCYJNA I JEJ POZYTYWNE KONOTACJE}

Analiza transakcyjna - AT (ang. TA - transactional analysis) została zapoczątkowana $\mathrm{w}$ drugiej połowie lat 50. ubiegłego wieku jako jedna z nowych koncepcji psychoterapeutycznych. Inspiracje dla tego kierunku można odnaleźć zarówno w psychoanalizie, jak i w silnie oddziałującej wówczas na świadomość terapeutów psychoterapii humanistycznej. W zamierzeniu jej twórcy - Erica Berne’a (19101970) - AT miała być przede wszystkim terapią grupową sytuującą się w obszarze psychiatrii społecznej (Berne 1961, 1963). Obecnie przeważa jednak pogląd, że analiza transakcyjna to nade wszystko pewien kierunek psychologii społecznej. Robert F. Massey pisze: „Chociaż Berne zaproponował analizę transakcyjną jako psychiatrię społeczną, to jej konstrukcję można rozumieć jako psychologię społeczną. [...] Jako psycholog społeczny Berne oferował wgląd w komunikację, socjalizację, wspólnotę osób i struktur. Współzależności między specjalizacjami (kliniczną, doradczą, edukacyjną, organizacyjną) są bardziej widoczne, gdy analiza transakcyjna jest spostrzegana jako psychologia społeczna" (Massey 1996, s. 91). Zgodnie z przyjętą przez Międzynarodowe Towarzystwo Analizy Transakcyjnej (ITAA - International Transactional Analysis Association) definicją: „Analiza transakcyjna jest teorią osobowości i systemem psychoterapii ukierunkowanej na osobisty rozwój i zmianę" ${ }^{\prime}$. Jako teoria osobowości proponuje model struktury osobowości, posługując się stanami Ja (Ja-Rodzic, Ja-Dorosły i Ja-Dziecko), które pozwalają zrozumieć sposób funkcjonowania człowieka i sposób, w jaki ludzie wchodzą we wzajemne interakcje. Ponadto analiza transakcyjna pozwala za pomocą skryptu życiowego (life script) wyjaśnić przyczynę naszych aktualnych wzorców zachowań, które zostały wyuczone w dzieciństwie. Dzięki temu rozumieniu naszych stanów Ja oraz ograniczeń, jakie stwarza skrypt, możemy osiągnąć zdrowie psychiczne, autonomię, będącą zasadniczym celem AT, poprzez własną świadomość, spontaniczność, zdolność do intymności oraz odpowiedzialność.

Już podstawowe założenia analizy transakcyjnej, na której zbudowana jest cała koncepcja, posiadają konotacje zbliżające ją do psychologii pozytywnej. Kryteria te zakładają, że „ludzie są OK”. Oznacza to, że każdy człowiek zasługuje na afir-

\footnotetext{
${ }^{1}$ https://itaaworld.org/ [dostęp: 4.01.2018].
} 
mację z samego faktu własnego istnienia. Ludzie są zatem jednakowo wartościowi i równi w swoim człowieczeństwie. Nieakceptowane mogą być tylko zachowania danej osoby, nigdy natomiast nie należy negować egzystencji samego człowieka. Kolejnym fundamentalnym kryterium całej koncepcji jest przekonanie, że każdy posiada zdolność myślenia i podejmowania decyzji w swojej sprawie. Wyklucza się tylko w tych przypadkach osoby o masywnie zmąconej świadomości, np. mające uszkodzony centralny system nerwowy czy będące w stanie silnego epizodu psychotycznego. Jednak nawet w tych sytuacjach szczątkowa świadomość pozwala niejednokrotnie na nawiązanie relacji i pozostawienie danej osobie prawa wyboru. Ostatnim z wymienianych kryteriów (Stewart, Joines 2016, s. 8-9) jest przeświadczenie, że podejmowane przez ludzi decyzje oraz zachowania mogą się zmieniać. Stwarza to dla każdego człowieka ukierunkowaną i korzystną perspektywę prorozwojową. Komplementarność powyższych złożeń, które od początku powstania AT towarzyszyły tej koncepcji, gdyż wynikały z inspiracji psychoterapii humanistycznej, znacznie zbliżają nas do obecnego rozumienia psychologii pozytywnej.

Warto przypomnieć, że autonomia $\mathrm{w}$ analizie transakcyjnej nieodwołalnie do czasów Erica Berne’a była związana ściśle z trzema pojęciami: świadomość, spontaniczność i intymność (Berne 1987, s. 193-197). Dopiero połowa lat 50. przyniosła refleksję u wielu autorów, że dotychczasowy zakres autonomii należy poszerzyć o jeszcze jedną kategorię - odpowiedzialność (Bonds-White 1995; Van Beekum 1995). Dwaj badacze: Servaas van Beekum oraz Bastianne Krijgsman, podejmują jednak próbę empirycznej falsyfikacji dotychczasowych ustaleń (Van Beekum, Krijgman 2000, s. 52-57). Sześcioletni projekt badań w Holandii dostarczył cennych wskazówek tego, co ta koncepcja naprawdę oznacza. Analiza czynnikowa potwierdziła hipotezy Berne’a, że autonomia przejawia się w zdolności do świadomości, przez co rozumie się ejdetyczne poznanie, brak symbiotyczności, dostępność wewnętrznego dialogu, zdolność do interpretacji i tworzenia rzeczywistości, intuicję, percepcję rzeczywistości, gotowość pomocy, zajmowania się złożonością, formułowania nowości itd.

Z kolei spontaniczność to umiejętność wyrażania uczuć i myśli, niezależność, niepodejmowanie gier interpersonalnych, gotowość do podejmowania decyzji, transgresyjność, otwartość umysłu, a czasem też buntowniczość. Intymność przejawia się natomiast m.in. zdolnością budowania bliskich relacji z innymi i odnoszeniem się do nich z szacunkiem, szczerością, akceptacją wolności i wyborów innych osób. Natomiast odpowiedzialność, jako właściwość uzupełniająca powyższe składowe, to chęć posiadania własnych opinii, interpretacji rzeczywistości, co czasem wiąże się z kwestionowaniem uznanych autorytetów, stałość własnego zachowania, tożsamość, aktywność i indywidualność, znoszenie niepowodzeń czy świadomość własnego miejsca w życiu (Van Beekum, Krijgman 2000, s. 53). Charakterystyka 
powyższych oraz jeszcze innych cech i odpowiadających im przeciwstawnych wskaźników pozwoliła na zbudowanie kwestionariusza, który posłużył następnie do realizacji badań (Van Beekum, Krijgman 2000, s. 54).

Analizy pokazały również, że autonomia to zdolność do budowania dobrego kontaktu z innymi. Wpisuje się to w przesłanie psychologii pozytywnej, która sytuuje się między skrajną koncentracją na indywidualizmie jednostki a radykalnym kolektywizmem, o tym, że autonomię należy opisywać poprzez dobry kontakt z samym sobą oraz poprzez optymalny kontakt $\mathrm{z}$ innymi, zgodnie z maksymą Martina Bubera: Ja - Ty (Buber 1992). Wspomniani autorzy piszą: „Chcieliśmy pozostawić czytelnika $\mathrm{z}$ filozoficznym pytaniem: czy można być niezależnym bez kontaktu $z$ innymi? Tak jak potrzebujemy doświadczania granic wolności, aby być autonomicznymi, tak potrzebujemy związków z innymi. Prawdziwa autonomia może oznaczać, że możemy w pełni doświadczać siebie, gdy przechodzimy pomiędzy kontaktem ze sobą i kontaktem z drugim" (Van Beekum, Krijgman 2000, s. 57). Osób zaznajomionych z AT nie trzeba przekonywać, że problem ten urzeczywistnia się poprzez tzw. analizę pozycji życiowych (Harris 1987, s. 56-70 i nn.). Bardzo podobne stanowisko zajmuje Liewe Koopmans, gdy pisze: „Autonomia powstanie tylko w relacji do drugiej osoby. To tworzy wewnętrzne doświadczenie wolności. To wewnętrzne doświadczenie jest przede wszystkim czymś, do czego dążymy, a czasami, jeśli pojawi się tylko na krótko, zmienia coś w naszym życiu" (Koopmans 2019, s. 7).

Trudno zaprzeczyć, że poczucie autonomii jest jednym z istotnych predyktorów decydującym o przekonaniu jednostki o jakości własnego życia, jednego z kluczowych pojęć pozytywnej psychologii, choć jednocześnie nie często zauważa się ten aspekt. W jednym $\mathrm{z}$ artykułów poświęconych AT czytamy: „z rzadka tylko dostrzega się wartość autonomii jednostki jako ważnego czynnika wpływającego, a niejednokrotnie wręcz decydującego o jakości życia poszczególnych osób oraz całych zbiorowości ludzkich. Celowym wydaje się zatem ukazanie znaczenia i roli autonomii w życiu człowieka z perspektywy jednej z koncepcji psychologicznych, jaką jest analiza transakcyjna" (J. Jagieła, 2015, s. 17). Dalej w artykule odnajdujemy próbę wykazania takich związków.

Wielu przedstawicieli analizy transakcyjnej podejmuje próbę ukazania podobieństw i różnic łączących AT z psychologią pozytywną. Na uwagę zasługuje tu obszerny artykuł Rosemary Napper, która w sposób bardzo osobisty dzieli się swoimi poszukiwaniami dziedzin aktywności i sprawiedliwości społecznej, które doprowadziły ją zarówno do różnych obszarów zastosowań analizy transakcyjnej, jak i odkrycia dla siebie psychologii pozytywnej (Nappar 2009, s. 61-74). Autorka stara się odpowiedzieć, czym według niej jest analiza transakcyjna i dochodzi do wniosku, że jest to zbiór map i metafor, które stwarzają możliwość dobrej 
komunikacji między ludźmi w różnych kulturach oraz na wszystkich poziomach wykształcenia. Jako swoisty metajęzyk może dostarczyć wiele pozytywnych pomysłów psychologicznych. Jednym z bogactw AT jest jej rozległość, poczynając od behawioralnych i poznawczych sposobów pracy, po psychodynamiczne ujęcia oraz autoterapię. Zamiast zatem skupiać się na niuansach, cieszmy się - pisze Napper i przekazujmy wartość koncepcji we wszystkich obszarach współczesnego życia.

Z kolei psychologia pozytywna, dzięki licznie prowadzonym badaniom, które autorka przytacza w swoim artykule, jest w stanie dostarczyć dowodów empirycznych potwierdzających słuszność koncepcji AT. Autorka zajmuje jednak dość sceptyczne stanowisko wobec badań, które koncentrują się na „obiektywności”, na rzecz współczesnej filozofii konstruktywistycznej, która skupia się bardziej na „subiektywności”. Nieco prowokująco stwierdza: „Czy to naprawdę ważne, czy istnieją jakiekolwiek dane empiryczne mogące dostarczyć «prawdy» za konstruktami?" (Nappar 2009 s. 72). I dodaje, że być może odpowiedź na to pytanie brzmi „tak”, ale tylko wtedy, jeśli weźmiemy pod uwagę upowszechnianie AT wśród ludzi, „którzy wierzą w empirię”. Łatwo dostrzec pewne sprzeczności w tym rozumowaniu.

W całym tekście Napper wskazuje bowiem na kilka satysfakcjonujących połączeń i różnic w niezweryfikowanych empirycznie konstruktach analizy transakcyjnej z danymi empirycznymi psychologii pozytywnej. Zauważa, że zarówno jedna, jak i druga dziedzina, trochę rozmijają się ze znaczeniem problemów, którymi się zajmują. Słowo „transakcja” nie brzmi zachęcająco i odnosi się bardziej do sfery finansowej. Działa odstraszająco nawet dla wykształconych ludzi. Zawsze dziwiło autorkę, dlaczego nie używa się bardziej zachęcających określeń np. „analiza skryptów” czy „psychologia autonomii”. Natomiast psychologia pozytywna może sugerować Zespół Pollyanny z samozadowoleniem i radosnym podejściem do pop-psychologii, która unika wszystkiego, co negatywne.

Wskazuje na wartość dla psychologii pozytywnej pięciu podstawowych pojęć analizy transakcyjnej: Okness, prawo do dokonywania własnych wyborów, autonomia, otwartość komunikacyjna oraz zawieranie kontraktów. Zauważa również, że wyodrębnione przez Seligmana trzy rodzaje podejścia do życia tj. życie przyjemne, zaangażowane i sensowne (Seligman 2003), stwarza korzystne warunki dla kategoryzacji skryptów. Można w ten sposób szukać odpowiedzi u klientów na pytanie, w jaki sposób odnajdują przyjemność w życiu, w jakim stopniu są zaangażowani i gdzie szukają sensu. Być może zobaczymy dzięki temu, biorąc pod uwagę analizę strukturalizacji czasu, że życie skoncentrowane na szukaniu przyjemności charakteryzuje się jednostronnym zaspokajaniem własnych głodów oraz jednostronnym odbieraniem znaków zauważenia i w konsekwencji polega na wycofaniu, rytuałach i rozrywkach. Natomiast życie zaangażowane ma charakter 
dwukierunkowy, skupiający się na aktywności oraz intymności. Życie sensowne wykraczałoby poza bycie zaangażowanym $\mathrm{w}$ relacje z innymi i dwie wcześniejsze kategorie oraz koncentrowałoby się na działaniach na rzecz szerszej społeczności.

Przywołując zestaw 24 mocnych stron podzielonych na sześć cnót (mądrości i wiedzy, odwagi, relacji do innych, sprawiedliwości, umiarkowania, transcendencji), wyodrębnionych przez Seligmana (2003, s. 137-161), autorka zauważa ich podobieństwo do cech składających się na model zintegrowanej osobowości. Zintegrowany stan Ja-Dorosłego sprzyja pozytywnemu funkcjonowaniu człowieka w wielu wymiarach: „Integracja wewnętrzna sprzyja nade wszystko kongruencji, czyli autentyczności wyrażającej się zgodnością między stanami osobowości a przekazem siebie $w$ kontaktach $z$ innymi. Nie sposób również nie zauważyć, że spójność osiągnięta w procesie integracji służy w wysokim stopniu, jak żaden inny czynnik, osiągnięciu przez jednostkę własnej tożsamości” (Jagieła 2013, s. 136). Osoba niespójna wewnętrznie charakteryzuje się dezintegracją w wielu sferach swojej psychiki. Mówiąc najprościej, co innego myśli, a co innego robi; zapewne też co innego czuje, a w konsekwencji skłonna jest w co innego wierzyć. Trudno zatem taki stan uznać za pozytywny w wymiarze psychologicznym.

Oprócz Rosemary Napper problematyką związków między analizą transakcyjną a pozytywną psychologią zajmował się też James R. Allen (2006, s. 120-133). Poddał on ocenie długotrwałe skutki traumy oraz działania interwencyjne, jakie wiązały się z terrorystycznym zamachem bombowym na jeden z budynków federalnych w Oklahoma City w kwietniu 1995 roku. Autor, rzecznik podejścia konstruktywistycznego (a mówiąc precyzyjniej neurokonstruktywistycznego Neuroconstructivist Transactional Analysis), w AT analizuje z punktu widzenia analizy transakcyjnej różne stany posttraumatyczne. Dostrzega również znaczenie podejścia bliskiego pozytywnej psychologii, w tym: docenianie przyjaźni, budowanie umiejętności korzystania ze swoich mocnych stron czy angażowanie się w rozwój osobisty i rekonstrukcji tożsamości osób dotkniętych tą traumą. Wskazuje, że są to cechy bliskie podejściu transakcyjnemu jako inicjatywom oraz wysiłkom na rzecz ochrony zdrowia psychicznego, będących nie tylko brakiem patologii, lecz także odpowiedzią na coraz większą potrzebę budowania odporności psychicznej i osobistych kompetencji.

Należy również wspomnieć o autorze reprezentującym z kolei nurt edukacyjnej analizy transakcyjnej, którym jest Giles Barrow. W swoim artykule pod znamiennym tytułem: Cudowny świat, piękni ludzie: przeformułowanie analizy transakcyjnej jako psychologii pozytywnej postuluje on przeformułowanie tradycyjnego w AT modelu stanów ego, co jego zdaniem będzie miało szczególne implikacje dla praktycznego wymiaru tej koncepcji (Barrow 2007, s. 206-209). Autor proponuje zastąpienie dotychczasowego układu: Rodzic - Dorosły - Dziecko 
schematem odwróconym; Dziecko - Dorosły - Rodzic. Stan Ja-Dorosły pozostaje na swoim miejscu, jedynie struktura Ja-Rodzic oraz Ja-Dziecko zmieniają swoje dotychczasowe położenie. Stawia hipotezę, że zmiana tego tradycyjnego porządku w świadomości transakcjonalistów może przyczynić się do rozumienia ludzkiego doświadczenia i dynamiki interpersonalnej. Według Barrowa usytuowanie Dziecka na szczycie tego modelu, jako synonimu źródła szczęścia i nadziei, a stanu Rodzica, jako bazowego podstawy poczucia bezpieczeństwa, mądrości i wsparcia, zmieni optykę pojmowania transakcyjnej struktury osobowości. Kieruje to uwagę na pozytywne aspekty i wartości, które w dotychczasowym schemacie były zaniedbane. Powstanie AT miało miejsce niedługo po doświadczeniu II wojny światowej, gdy psychologia stała się w dużej mierze nauką służąca uzdrawianiu i naprawianiu szkód w ludzkim funkcjonowaniu. Nie ma jednak wątpliwości, że intencje Erica Berne’a były jednak znacznie szersze i wiązały się z pragnieniem zaproponowania metody, która daje nadzieję i przywraca ludziom poczucie szczęścia.

Barrow pisze: „Wierzę, że analiza transakcyjna ma duże znaczenie dla rozwoju psychologii pozytywnej. Jako przedstawiciele społeczności transakcjonalistów mamy zarówno koncepcję, jak i język, który możemy rozwijać, aby służyć w cudowny sposób ludzkim zdolnościom, sile i skuteczności" (Barrow 2007, s. 207). Jako przykłady podaje siłę i jakość życia wiążącą się ze skryptowymi driverami, budowanie zdrowego partnerstwa poprzez zawieranie trójstronnych kontraktów czy rozwiązania, jakie można czerpać z Trójkąta Zwycięzcy. Powyższe przykłady rezonują $\mathrm{w}$ wysokim stopniu $\mathrm{z}$ celami teorii pozytywnejpsychologii.

Wśród różnych obszarów implementacji analizy transakcyjnej, wykraczających poza problematykę psychoterapii, pojawiają się treści związane z coachingiem, które $\mathrm{w}$ wielu zakresach pokrywają się z aspektami psychologii pozytywnej. Jako dziedzina poszukująca dopiero swojego miejsca w domenie nauki podejmuje kwestie pomocy i kierowania rozwojem umiejętności oraz kompetencji danej osoby w niepowtarzalnej i nacechowanej wzajemnym zaufaniem relacji partnerskiej między trenerem (coachem) lub grupą a osobą poszukującą wsparcia w realizacji postawionych sobie celów. Ewa Sokołowska odpowiadając na pytanie „Czy analiza transakcyjna może być użyteczna w coachingu?”, pisze o analizie transakcyjnej: „Koncepcja ta odpowiada na zapotrzebowanie coachingu, jakim jest korzystanie z teorii - również z dziedziny psychologii - dla uporządkowania pojęciowego i dla zdobycia odpowiedniej inspiracji. Daje się też wpisać w trend psychologii pozytywnej. AT opisuje mechanizmy prawidłowego rozwoju człowieka bez zbytniej koncentracji na patologii" (Sokołowska 2013, s. 41). Wydaje się jednak, że inkluzja problematyki edukacyjnej w obszar analizy transakcyjnej przyczyniła się też w znaczący sposób do przesunięcia zainteresowań AT w kierunku pozytywnej psychologii. 


\section{POZYTYWNE IMPLIKACJE EDUKACYJNEJ ANALIZY TRANSAKCYJNEJ}

Zainteresowanie edukacyjnymi zastosowaniami analizy transakcyjnej sięgają samych początków powstania tej koncepcji, a zatem początków lat 60 . ubiegłego wieku, kiedy zwracano uwagę na wartość AT dla budowania pozytywnych relacji między nauczycielem i uczniem oraz unikania destrukcyjnych gier psychologicznych w klasie szkolnej (Soles 1963, s. 97-110). Obecnie mówi się wręcz o pedagogice transakcyjnej jako wyspecjalizowanej dziedzinie, która w przypadku nauczycieli byłaby - jak twierdzi Wolfgang Kausler - istotną częścią kompetencji zawodowych nauczyciela (Kausler 2018, s. 130-133).

Choć niektórzy autorzy podkreślają nieuzasadniony prymat problematyki psychoterapeutycznej w tej koncepcji, stawianej na pierwszym miejscu w stosunku do pozostałych aplikacji AT, takich jak kwestie organizacyjne czy właśnie edukacyjne, to pomimo to tematyka kształcenia i wychowania znalazła w całej tej teoretycznej propozycji oraz jej praktycznych zastosowaniach stałe i niekwestionowane miejsce. Inkluzja rozwiązań i modeli edukacyjnych w AT przyczyniła się, jak można w sposób uzasadniony zakładać, do ukierunkowania rozwoju dziedziny w jeszcze większym stopniu w kierunku psychologii pozytywnej.

Wymieńmy zatem tych autorów i ich propozycje, które wydają się najbardziej potwierdzać powyższą tezę. Koncepcja płynności funkcjonalnej (FF - functional fluency) Susannah Temple w początkowym zamierzeniu autorki miała być adresowana głównie do nauczycieli. Oni to bowiem dzięki swojemu pozytywne$\mathrm{mu}$ funkcjonowaniu $\mathrm{w}$ relacjach interpersonalnych stwarzają najlepsze warunki zaistnienia oddziaływań pedagogicznych. Twórczyni zaproponowanego modelu w jednym ze swoich artykułów pisze, że podczas wielu lat pracy w charakterze nauczycielki przyszedł jej do głowy pomysł użycia terminu „płynność funkcjonalna”, który kojarzył dobre funkcjonowanie społeczne człowieka z profesjonalizmem. Czytamy: „Podobnie, jak operowanie językiem może być płynne, tak też integracja może wykazywać elastyczność i równowagę, a także rzeczywiste umiejętności. Mój model dostarcza mapę pozytywnych i negatywnych trybów behawioralnych. Model ten jest pomocny ludziom, aby rozpoznać i wzmocnić ich skuteczność, tak aby mogli poszerzyć i wzbogacić siebie w twórczy sposób, nie skupiając się na błędach i negatywnych zachowaniach" (Temple 2004 s. 11). Pozytywne tryby są tu kierunkiem, w jakim należy podążać.

Nie wchodząc dokładnie w omówienie całej koncepcji, która w tekście Znaczenie modelu plynności funkcjonalnej Susannah Temple (FF - functional fluency) dla edukacyjnej analizy transakcyjnej (Jagieła, 2017, s. 19-48) przybliża polskiemu czytelnikowi zarówno drogę, jak i charakter pojawiających się tu rozwiązań, zwróćmy jedynie uwagę na węzłowe kwestie. Kluczowe znaczenie ma tu rozdzielenie 
istniejącego w AT modelu strukturalnego od funkcjonalnego, jak również używanie terminu "tryb” na określenie manifestacji ludzkich zachowań w odróżnieniu od „stanów ego", jak działo się to tradycyjnie. Pozwala to, zdaniem autorki, uniknąć nieporozumień, w momencie gdy mówimy o wewnętrznych stanach Ja czy też koncentrujemy się na samych zachowaniach. Pomaga to ludziom zauważyć, że termin „tryb” czyni ich właścicielami ich własnych zachowań.

Kolejnym elementem modelu, który jej twórczyni określa jako behawioralną manifestację zintegrowanego stanu Ja-Dorosły, są wyodrębnione opcje funkcjonowania. Wielokrotnie podkreśla, że mają one szczególne znaczenie dla rozwoju osobistego i zawodowego nauczycieli. Opcje te dotyczą: przywództwa, opieki, kooperacji z innymi, spontaniczności oraz - tak jak to przetłumaczono na język polski - umiejętnej kalkulacji. Każda z tych opcji posiada zarówno pozytywne, jak i negatywne aspekty, np. spontaniczność może być wyrazem kreatywności, ale w swej negatywnej odmianie może znamionować niedojrzałość czy lekkomyślność. Z kolei przywództwo może mieć charakter dominacji, a nawet apodyktyczności, albo pozytywnej oraz inspirującej strukturalizacji sytuacji tego wymagających, opieka może mieć charakter wspierający, lecz również pobłażliwości i tego, co w AT nazwano przesłodzeniem, czyli niczym nieuzasadnionym udzielaniem "głasków”. Związki z innymi nabierają czasem postać kooperacji, ale też, co jest bardzo charakterystyczne, antagonistycznej postawy między uległością a buntem (Jagieła, 2017, s. 32). Osoba, która podejmie próbę zmierzenia się z tym modelem w swojej aktywności życiowej, może najpierw zdiagnozować, a później wybrać podkreślmy: wybrać! - pozytywną opcję, którą pragnie w sobie rozwijać. Rozpoznać własną opcję, którą dotychczas preferowaliśmy, a która nierzadko nie przynosiła zadawalających relacji z innymi. Odbywa się to za pomocą specjalnie skonstruowanego psychometrycznego narzędzia badawczego pomiaru FF określanego mianem Indeksu Płynności Funkcjonalne Temple (TIFF॰ - Temple Index of Functional Fluency). Autorka nazywa wspomniane narzędzie instrumentem rozwoju osobistego mającym na celu wzmocnienie motywacji do zmiany własnego pozytywnego zachowania (Temple 2015, s. 12).

Na znaczenie koncepcji płynnej funkcjonalności z jej pięcioma pozytywnym trybami w kontekście związków z pozytywnymi emocjami zwraca też uwagę przywołana wcześniej Rosemary Napper. Podkreśla, że te sposoby funkcjonowania, które wynikają z pozytywnych emocji, budują zasoby fizyczne i społeczne, tworzą więzi i przywiązanie, dostarczają wsparcia, stanowią o zasobach intelektualnych (w tym kreatywności), przyczyniają się w ogólnym rachunku do rozwoju mózgu czy samopoznania (Napper 2009, s. 67). Jest rzeczą oczywistą, do której zapewne nie trzeba nikogo przekonywać, że wszytki powyższe czynniki w sposób niezwykle korzystny korelują z problematyką edukacyjną. 
Obok umiejętności społecznego funkcjonowania niebagatelną rolę odgrywają również umiejętności funkcjonowania $\mathrm{w}$ sferze emocjonalnej. W przypadku AT można odwołać się do koncepcji autentycznych lub zastępczych uczuć. Stan Ja-Dziecko jest związany z przeżywaniem emocji, które określane bywają jako uczucia autentyczne (authentic feeling). Są to spontaniczne, prawdziwe i pozbawione cenzury reakcje emocjonalne na różnego typu zdarzenia, sytuacje czy doświadczenia. Jednak niektóre osoby nauczyły się w dzieciństwie skutecznie ukrywać uczucia autentyczne, tworząc system rakiet (racket) uczuciowych. Nazywanych też w sposób bardziej chyba trafny siatką uczuć zastępczych (racket feeling). Uczucia zastępcze mogą być traktowane jako rodzaj obrony przed zagrażającymi, nieakceptowanymi i wypieranymi emocjami. Uczucia, które nie są dopuszczanie do świadomości, niosą ze sobą wiele psychicznych spustoszeń, gdyż oddalają od autentycznych i rzeczywistych emocji oraz od innych. Czynią z jednostki osobę pozbawioną siły, nierzadko bierną i pozostającą w poczuciu własnej krzywdy. Stąd też problem ten nie może umknąć uwadze pedagogiki. Wincenty Okoń jako jedną ze strategii w procesie nauczania - uczenia się wyodrębnił strategię emocjonalną „E” (Okoń 1987, s. 22), Bolesław Niemierko zaś zwrócił uwagę na jeden z modeli uczenia się przedmiotów ogólnokształcących jako model Delta związany z przezywaniem uczuć (Niemierko 2007, s. 107). Jednak najpełniej o rolę przeżyć w procesie uczenia się upomniał się Władysław P. Zaczyński (Zaczyński, 1990), wskazując, że rzeczywistość wymaga wielu sposobów poznania, a autentycznie przeżywane uczucia są niewątpliwie jedną z nich i warunkują efektywność uczniowskiej aktywności edukacyjnej.

Z kwestią roli pozytywnych emocji wiąże się też zagadnienie udzielania pozytywnego wsparcia w postaci znaków zauważenia, jakie rodzice i nauczyciele udzielają lub mogą udzielać dziecku. Pozytywne bezwarunkowe wsparcie, które jest wyrazem miłości i akceptacji, znajduje się w opozycji nie tylko w stosunku do negatywnych reakcji na obecność dziecka, ale także do pozytywnych „głasków”, udzielanych jednak w sposób warunkowy, które mogą prowadzić do różnych przejawów wychowawczych manipulacji. Na znaczenie kompetencji emocjonalnych pod pojęciem Emotional Literacy (EL) zwraca też uwagę Claude M. Steiner, bliski przyjaciel i uczeń Berne'a. Termin literacy jest stosowany w języku angielskim dla zilustrowania zdolności do czytania i pisania, jednak zdaniem Steinera może być zastosowany również w poznawaniu i opanowywaniu sfery emocji. Osoby zagubione $\mathrm{w}$ sferze doświadczania i przeżywania własnych uczuć określił mianem emocjonalnych analfabetów (Steiner 1984, s. 162-174; 1996, s. 31-39 ). Nie są w stanie emocjonalnie komunikować się z innymi, ani nie wiedzą, co robić lub myśleć, gdy doświadczają tego rodzaju przeżyć. Odbija się to też na ich kondycji psychicznej i fizycznej, a przejawia m.in. różnego rodzaju uzależnieniami. Oczywiste, 
że „choć powyższa problematyka nie dotyczy wprost zagadnień edukacyjnych, to każdy musi przyznać, że ma ona swoje implikacje o takim właśnie charakterze, które dotyczyć mogą choćby odpowiedzialności za interakcje, jakie mają miejsce na terenie szkoły, oraz to, co w konsekwencji z nich wynika" (Jagieła 2016, s. 248).

$\mathrm{Na}$ cały szereg map pojęciowych i modeli analizy transakcyjnej, mających znaczenie w organizacji procesu edukacyjnego oraz korespondujących też w wysokim stopniu z pozytywną psychologią, zwraca uwagę Sylvia Schachner (2016, 39-45). Wymienia tu między innymi warunki, jakie musi spełniać proces kształcenia, aby szkoła, nauczyciel i uczniowie mogli osiągać pozytywne efekty dydaktyczne. Uważa, że konieczne jest w takich przypadkach odwołanie się do zaspokojenia trzech uczniowskich potrzeb („głodów transakcyjnych”). Są nimi pragnienie działania w określonej strukturze, akceptacja dla uczniowskiej obecności oraz wysiłku, a także potrzeba stymulacji, pobudzania dziecięcej ciekawości i kreatywności. Uczniowie w swojej aktywności powinni też doświadczać poczucia bezpieczeństwa (ochrony), aby mogli odkrywać swoje zdolności społeczne i intelektualne. Nauczyciele, oprócz swojej siły wyrażającej się umiejętnością nauczania, zobowiązani są również pozwalać uczniom na własne myślenie, odkrywanie świata oraz przeżywanie w czasie nauki czegoś nowego lub niezwykłego. Nauczyciel, jakiego wyobraża sobie Schachner, powinien charakteryzować się znaną w AT pozytywną postawą życiową określaną jako Okness. Przyjęcie każdej innej pozycji egzystencjalnej rodzi określone negatywne konsekwencje i nie przyczynia się do budowania właściwej relacji między nim samym a uczniami. Dobrze służy tworzeniu ze strony nauczyciela pozytywnych odniesień kierowanie się ustalonymi zasadami działania oraz umiejętność zawierania kontraktów z uczniami.

Wspomnijmy jeszcze o jednym modelu transakcyjnym, którego pozytywny psychologicznie wymiar może stanowić konstruktywną odpowiedź na negatywne zjawiska, jakie czasem mają miejsce na terenie szkoły. Mowa tu o poruszanych często w ostatnim okresie zjawiskach przemocy, agresji czy nawet brutalności. Osoby w nich uczestniczące przyjmują zgodnie z modelem Stephena Karpmana przemienne role: Prześladowcy, Ofiary i Ratownika (Karpman 1968, s. 39-43). Pułapka Trójkąta Dramatycznego (Drama Triangle) polega na tym, że ludzie w nim uczestniczący nie mogą wyjść z akinezji wzajemnego uwikłania, co blokuje ich możliwość konstruktywnego rozwiązania tego problemu. Rozwiązanie tej negatywnej zależności jest podsuwa Alice Choy w koncepcji Trójkąta Zwycięzcy (Winner's Triangle). Wskazuje ono na konieczność przyjęcia przeciwstawnych ról psychologicznych: Asertywny, Troszczący się, Wrażliwy/Potrzebujący (Choy 1990, s. 40-46). Problem dramatu przemocy szkolnej można rozwiązać przez uwzględnienie charakterystyki ról Prześladowcy, Ofiary i Ratownika z przyjmowanymi przez nich stanami Ja: Rodzica, Dorosłego i Dziecka oraz realnymi uczestnikami 
tego zdarzenia, jakimi są uczniowie, nauczyciele i rodzice. Tworzy to kolejny pozytywny trójwymiarowy schemat, który wart jest uwzględnienia, a który można zdefiniować jako Model Przemocy Szkolnej (Jagieła 2018a, s. 41-61).

Niech cztery powyższe przykłady będą potwierdzeniem, że obecność problematyki edukacyjnej przyczyniła się w stopniu wyższym, niż można było niekiedy zauważyć, do wykazania związków, jakie istnieją między analizą transakcyjną a koncepcją pozytywnej psychologii.

\section{WNIOSKI}

Bez wątpienia pojawienie się w psychologii idei pozytywnego spojrzenia na ludzki los i afirmatywnego postrzegania ludzkiej egzystencji wniosło konieczny balans do tradycyjnie uprawianej dyscypliny, często nadmiernie skoncentrowanej na patologii i deficytach. Psychologia upomniała się o pojęcia i zjawiska umykające do tej pory uwadze badaczy. Upomniała się o zdrowie i jakość życia. Jednocześnie jednak trudno nie ulec wrażeniu, że autorzy podejmujący wspomnianą problematykę zamknęli się w kręgu podobnych problemów i definicji. Sięgając po kolejną książkę o tej tematyce, łatwo przewidzieć jej treść. Mimo że czasem urzekają one pozytywnym i pełnym godności nastawieniem do człowieka i jego zmaganiami z nadaniem własnemu życiu głębokiego sensu, to jednak rozczarowują niejednokrotnie powierzchownością refleksji i naiwnością. Jak stwierdził recenzent jednej z książek - przypominają potoczne powiastki z morałem.

Ukazana w tym opracowaniu perspektywa analizy transakcyjnej wraz z implementacjami sięgającymi edukacji stwarza możliwości poszerzenia zakresu dotychczasowej problematyki o nowe zagadnienia. Może mieć ona znacznie w kształceniu i wychowaniu dzieci oraz młodzieży, jak również osób dorosłych, pragnących budować pozytywne relacje międzyludzkie. Obecnie edukacja stanowi bowiem nie tylko wyzwanie zmuszające do dodatkowego wysiłku, ale także obszar realizacji ludzkich pragnień.

Na koniec należy zauważyć, że włączenie edukacji w obszar psychologii pozytywnej nie jest faktem odosobnionym i dotyczącym tylko analizy transakcyjnej. Na takie zależności zwróciło uwagę wielu autorów. Na przykład Magdalena Kolber w swoim artykule Zastosowanie psychologii pozytywnej w edukacji po przedstawieniu założeń teoretycznych psychologii pozytywnej i jej związków z edukacją prezentuje przykłady programów szkolnych, które powstały na gruncie przesłanek psychologii pozytywnej (Kolber, b.d.). Z kolei Anna Pluskota-Lewandowska dokonała szerokiego przeglądu literatury psychologicznej ubiegłego wieku, dostępnej również w zagranicznych bazach danych, i stwierdza, podobnie jak inni autorzy, 
zdecydowaną przewagę analizy negatywnych emocji (uprzedzeń, lęków, gniewu, agresji, depresji itd.) nad emocjami pozytywnymi (radości, zadowolenia, szczęścia itd.). W dalszej części swojego tekstu stara się uzasadnić możliwość praktycznej implementacji teorii psychologii pozytywnej w konteksty związane z szeroko pojętą edukacją i, co podkreśla, edukacją całożyciową.

W konkluzji swojego tekstu autorka stwierdza, że wzrastające wskaźniki depresji wśród młodych ludzi oraz ich niski poziom satysfakcji życiowej (mowa jest czasem wręcz o epidemii depresji) jest mocnym argumentem na rzecz wprowadzania tego nurtu do edukacji. Pozytywna edukacja jest tu definiowana przede wszystkim jako nauczanie pewnego rodzaju pozytywnych umiejętności oraz określana bywa jako edukacja dla szczęścia. Twierdzi się, że opanowywanie takich umiejętności, jak odporność psychiczna czy poczucie sensowności podejmowanych przez siebie działań, mogą i powinny być uczone w szkołach. Stanowią bowiem antidotum na depresję, zwiększają poczucie satysfakcji życiowej, a także są pomocą w nauce i wsparciem w rozwoju kreatywnego myślenia. Powołując się na poglądy Martina E.P. Seligmana, pisał: „Szkoła może być miejscem umożliwiającym młodym ludziom rozwój na szeroką skalę - zarówno zwiększania zasobów osobistych, jak i dobrostanu psychicznego. Szkoła wydaje się doskonałym miejscem do nauki owego dobrostanu oraz dla pozytywnych inicjatyw (prewencji i terapii pozytywnej) z prostego powodu - większość młodych ludzi uczęszcza do szkoły i spędza tam większą część swojego czasu (szczególnie w krajach, gdzie kształcenie elementarne jest obowiązkowe) (za: Pluskota-Lewandowska 2011, s. 171).

Można tylko żywić nadzieję, że edukacyjna analiza transakcyjna, wraz ze swym teoretycznym i badawczym dorobkiem, zostanie dostrzeżona jako jedna z orientacji psychopedagogicznych mogących przyczynić się do zwiększenia obecności pozytywnych aspektów nauczania i wychowania młodych ludzi (Jagieła 2018). Kolejne lata będą zapewne najlepszym weryfikatorem lub falsyfikatorem powyższych oczekiwań.

\section{LITERATURA}

Allen J.R., 2006, Oklahoma City Ten Years Later: Positive Psychology, Transactional Analysis, and the Transformation of Trauma from a Terrorist Attack. „Transactional Analysis Journal", 2(36), 120-133.

Barrow G., 2007, Wonderful World, Beautiful People: Reframing Transactional Analysis as Positive Psychology. „Transactional Analysis Journal”, 3(37), 206-209.

Berne E., 1961, Transactional analysis in psychotherapy: A systematic individual and social psychiatry. New York: Grove Press. 
Berne E., 1963, The structure and dynamics of organizations and groups. New York: Grove Press.

Berne E., 1987, W co graja ludzie? Psychologia stosunków międzyludzkich. Warszawa: Państwowe Wydawnictwo Naukowe.

Bonds-White F., 1995, The group in the individual and the individual in the group. Workshop presented at the annual conference of the International Transactional Analysis Association. San Francisco.

Buber M., 1992, Ja i ty. Wybór pism filozoficznych. Warszawa: Instytut Wydawniczy PAX. Carr A., 2009, Psychologia pozytywna. Nauka o szczęściu i ludzkich siłach. Poznań: Zysk i S-ka Wydawnictwo.

Choy A., 1990, The Winners Triangle. „Transactional Analysis Journal”, 1(20), 40-46. Colman A.M., 2009, Słownik psychologiczny. Warszawa: Wydawnictwo Naukowe PWN. Czapiński J. (red.), 2004, Psychologia pozytywna. Nauka o szczęściu, zdrowiu, sile $i$ cnotach człowieka. Warszawa: Wydawnictwo Naukowe PWN.

Fortuna P., 2012, Pozytywna psychologia porażki. Jak z cytryn zrobić lemoniadę. Sopot: Gdańskie Wydawnictwo Psychologiczne.

Haidt J., 2007, Szczęście. Od mądrości starożytnych po koncepcje współczesne. Gdańsk: Gdańskie Wydawnictwo Psychologiczne.

Harris T.A., 1987, W zgodzie z sobq i z toba. Praktyczny przewodnik po analizie transakcyjnej. Warszawa: Instytut Wydawniczy.

Jagieła J., 2013, Integracja osobowości jako wartość edukacyjna: perspektywa edukacyjnej analizy transakcyjnej. „Postawy Edukacji”, 6, 119-139.

Jagieła J., 2015, Autonomia a jakość życia. Perspektywa analizy transakcyjnej. „Dyskurs Pedagogiczny", 14, 15-25.

Jagieła, J., 2016, Emotional literacy. „Edukacyjna Analiza Transakcyjna”, 5, 245-249. DOI: 10.16926/eat.2016.05.15.

Jagieła J., 2017, Znaczenie modelu płynności funkcjonalnej Susannah Temple (FF functional fluency) dla edukacyjnej analizy transakcyjnej. „Edukacyjna Analiza Transakcyjna”, 6, 19-48. DOI: 10.16926/eat.2017.05.02.

Jagieła J., 2018, Edukacyjna analiza transakcyjna na tle innych orientacji psychopedagogicznych. Częstochowa: Wydawnictwo AJD.

Jagieła J., 2018a, Transakcyjny model przemocy szkolnej. „Studia Pedagogica Ignatiana”, 1(21), 41-61. DOI: 10.12775/Spi.2018.1.002.

Karpman S., 1968, Drama Triangle Script Drama Analysis. „Transactional Analysis Bulletin", 7(26), 39-43.

Kausler W., 2018, Transaktionsanalyse im Bereich Bildung. „Zeitschrift für Transaktionsanalyse", 2 (35), 130-133.

Kolber M. (b.d.), Zastosowanie psychologii pozytywnej w edukacji, opublikowano: https://repozytorium.ukw.edu.pl/handle/item/1716 [dostęp: 28.12.2018]. 
Koopmans L., 2019, Autonomy is also dependency. „TA Magazine. English Edition”, $1,7-11$.

Massey R.F., 1996, Transactional Analysis as Social Psychology. „Transactional Analysis Journal", 1(26), 91-99.

Napper R., 2009, Positive Psychology and Transactional Analysis. „Transactional Analysis Journal", 1(39), 61-74

Niemierko B., 2007, Kształcenie szkolne. Podręcznik skutecznej dydaktyki. Warszawa: Wydawnictwo Akademickie i Profesjonalne.

Okoń W., 1987, Wprowadzenie do dydaktyki ogólnej. Warszawa: PWN.

Pluskota-Lewandowska A., 2011, Pozytywnie w edukacji. „Kultura i Edukacja”, 3(82), 147-174.

Schachner S., 2016, Models of transactional analysis in educational management. „Edukacyjna Analiza Transakcyjna”, 5, 39-45.

Seligman M., 2003, Authentic happiness. London: Nicholas Brearly.

Seligman M.E.P., Parks A.C., Stern T., 2004, A balanced psychology and full life. „Philosophical Transactions of the Royal Society (B)”, 359, 1379-1381.

Seligman M.E.P., 2005, Positive Psychology. Positive Prevention and Positive Therapy. W: C.R. Snyder, S.J. Lopez (red.), Handbook of Positive Psychology (s. 4-9). New York: Oxford University Press.

Snyder C.R., Lopez S.J. (red.),2005, Handbook of Positive Psychology. New York: Oxford University Press.

Sokołowska E.,2013, Czy analiza transakcyjna może być użyteczna w coachingu? "Coaching Review”, 1 (4), 41-59.

Soles S., 1963, Social dynamics. A study of classroom games - Progress report. „Transactional Analysis Bulletin", 8(2) nr 8, 97-110,

Steiner C.M., 1984, Emotional Literacy. „Transactional Analysis Journal”,14(3), 162-174.

Steiner C.M., 1996, Emotional literacy training: The application of transactional analysis to the study of emotions. „Transactional Analysis Journal”, 26(1), 31-39.

Stewart I., Joins V., 2016, Analiza transakcyjna dzisiaj. Poznań: Dom Wydawniczy REBIS.

Temple S., 2004, Building self-awareness, opublikowano: https:/westtownapps.com/ $\bmod \times 2 /$ section-a/ [dostep: 7.01.2019].

Temple S., 2015, Celebrating Functional Fluency and Its Contribution to Transactional Analysis Theory. „Transactional Analysis Journal”, 1(45), 10-22. DOI:10.1177/0362153714568803

Van Beekum S., 1995, Learning about ego states and ego. Haarlern, Netherlands: 1AS International.

Van Beekum S., Krijgman B., 2000, From Autonomy to Contact. „Transactional Analysis Journal", 1(30), 52-57

Zaczyński W.P., 1990, Uczenie się przez przeżywanie. Warszawa: WSiP. 


\title{
"BECAUSE I'VE GOT HEALTH AND STRENGTH...” \\ EDUCATIONAL TRANSACTIONAL ANALYSIS FROM THE PERSPECTIVE \\ OF POSITIVE PSYCHOPEDAGOGY
}

\begin{abstract}
From the very beginning, transactional analysis (TA) in its psychotherapeutic dimension has been guided by the same assumptions which form the basis of positive psychology. This fact has been pointed out by a number of authors publishing in Transactional Analysis Journal. The implementation of transactional analysis into education and its problems, models and solutions additionally increase the involvement of this concept in contemporary positive psychology.
\end{abstract}

Keywords: transactional analysis, positive psychology, educational transactional analysis 